\title{
Doseljavanje stanovništva iz slovenskih krajeva u Čabarski kraj na temelju zabilješki u knjigama Status animarum
}

DOI: $10.11567 /$ met.29.1.3 UDK: 314.742(497.5-37 Čabar:497.4)"18/19"

Prethodno priopćenje

Primljeno: 28.2.2013.

Prihvaćeno: 18.4.2013.

\author{
Barbara Riman \\ Inštitut za narodnostna vprašanja, Ljubljana \\ barbara.riman@guest.arnes.si
}

\section{SAŽETAK}

Prostor Gorskoga kotara bio je u povijesti prostor raznih migracijskih procesa koji su utjecali na etničke karakteristike toga područja. Upravo su ti procesi razlog današnjega heterogenog sastava stanovništva. Cabarski kraj nije bio iznimka, te su u povijesti zabilježena doseljavanja stanovnika iz svih dijelova Habsburške Monarhije. Osobito je intenzivno bilo doseljavanje stanovništva u krajeve bliže Kupi i Čabranki. Razloge doseljavanja stanovništva i intenzitet njihova dolaska može se pratiti po zapisima u knjigama Status animarum (hrv. Stanje duša, slov. Družinske knjige). U knjigama Stanje $d u s ̌ a$ zabilježeni su razlozi dolaska ili odlazaka pojedinaca, ali i cijelih obitelji. Na temelju tih podataka mogu se izvući uopćeni zaključci za određeni geografski prostor i određeno političko-povijesno razdoblje, što je relevantna i vjerodostojna podloga za teorijska promišljanja i komparativnu analizu. Na taj način povijest određenoga kraja postaje povijest njegovih stanovnika, kako onih trajno naseljenih tako i doseljenih. U radu se razmatraju podaci o doseljavanju stanovništva na prostor Čabarskoga kraja, s naglaskom na doseljavanje stanovništva iz današnjih slovenskih krajeva u 19. i 20. stoljeću. Podaci dobiveni iz knjiga Stanje duša, koje potječu iz župa Čabarskoga kraja, upućuju na doseljavanje stanovništva, što dokumentira postojanje migracija iz slovenskih krajeva prema današnjim hrvatskim područjima, ali i obratno. Izneseni zaključci nadopunjeni su i ilustrirani podacima iz knjiga Status animarum koji potječu iz slovenskih župa Babno Polje i Jelšane te onima iz matičnih knjiga učenika osnovnih škola u Prezidu i Čabru.

KLJUČNE RIJEČI: Status animarum, Čabarski kraj, Gorski kotar, doseljavanje slovenskog stanovništva

\section{UVOD}

Gorski kotar s geografskog se motrišta može podijeliti na pet mikroregija, a jedna je od njih Čabarski kraj ${ }^{1}$ (Šafar, 1981: 12). On je krajnji sjevero-

1 Ostale su četiri mikroregije Središnji kraj, Severinski kraj, Kupska dolina i Drežnički ili 
zapadni dio Gorskoga kotara. Njegove su glavne geografske značajke kontrast visokoga gorskog masiva i duboko usječenih dolina rijeka Čabranke i Kupe. Važne su karakteristika kraja i gravitacija stanovništva Čabarskoga kraja prema Sloveniji, postupni pad broja stanovnika, i to uglavnom zbog prometne izolacije (čemu su pridonijele Autocesta Rijeka - Zagreb i Autocesta Ljubljana - Kopar) te posredna povezanost s regionalnim centrima (Rijeka). ${ }^{2}$ Valja napomenuti da je cesta Prezid - Delnice završena tek 1977. (Šafar, 1981: 18-19).

Upravo su taj položaj Čabarskoga kraja kao i njegova slaba prometna povezanost u povijesti, uvjetovali različite migracijske procese koji su utjecali na etničke karakteristike Gorskoga kotara te su razlogom današnjega heterogenog sastava stanovništva. Do prvih je migracija došlo za vrijeme stogodišnjih upada osmanskih četa u 15. stoljeću (Burić, 1983: 14-16), što je potaknulo prve stanovnike da se presele u obližnje, danas slovenske krajeve, jer su oni bili sigurniji. Nekoliko stoljeća nakon iseljavanja stanovništva, kada su osmanski upadi jenjali, stanovništvo se vratilo, ali je i počeo proces doseljavanja. Novo je stanovništvo dolazilo iz svih krajeva nekadašnje Habsburške Monarhije (Marković, 2003; Blaznik, 1979; Hreljević, 1964-1965). Doseljavanje se odvijalo u kolonizacijskim valovima, no zabilježeni su i pojedinačni dolasci (Marković, 2003: 31). ${ }^{3}$

Razloge za brojnije doseljavanje stanovništva u Gorski kotar tijekom 18. i 19. stoljeća valja tražiti u naglom razvoju regije. U tom su razdoblju izgrađene dvije ceste ${ }^{4}$ koje su povezale kontinentalnu Hrvatsku s Primorjem. Godine 1873. završena je željeznička pruga Rijeka - Karlovac. I ceste i željeznicu gradili su priznati majstori i radnici s prostora cijele Habsburške Monarhije. Izgradnja tih važnih prometnica zaobišla je prostor o kojem je riječ u ovom

\footnotetext{
Velikokapelski kraj (Šafar, 1981: 12).
}

2 Prometna je povezanost sa središnjim dijelom Gorskoga kotara (a onda i s ostalim dijelovima Hrvatske) sve do 1977. bila izrazito slaba. Za povezanost Čabarskoga kraja s ostalim dijelovima Hrvatske bile su važne dvije ceste, Brod na Kupi - Delnice i cesta iz smjera Prezida: Prezid - Parg - Tršće - Gerovo - Crni lug - Delnice. Danas su obje prometnice slabo održavane te je do Rijeke često lakše doći preko Slovenije nego kroz Gorski kotar.

3 O doseljavanju stanovništva u Gorski kotar pisalo se, iako uglavnom usputno. Valja napomenuti da je u knjizi Povijesna demografija Hrvatske prikazan samo jedan rad koji se isključivo bavi povijesnom demografijom Gorskoga kotara, djelo I. Karamana Komorska gospoštija Čabar 1787-1798. (Stipetić i Vekarić, 2004: 161).

4 Prva je cesta Karolina, koja se počela graditi 1726. Pripreme su trajale nekoliko godina. Bila je duga 105 kilometara i imala dva pravca, prema Bakru i prema Rijeci. Bila je to vrlo uska cesta sa strmim i oštrim zavojima (Horvat, 1980: 21-25). Druga je cesta Lujzijana, koja se gradila od 1804. do 1811. Dobila je ime po supruzi habsburškog cara Franje. Cesta je nastala zbog državnih i vojnih potreba. Gradnju je inicirao biskup Maksimilijan Vrhovec (Horvat, 1980: 119-120). 
tekstu, što je naglasilo obilježja njegove izoliranosti i nije potaknulo razvoj značajnijih gradskih središta (Bognar i Bognar, 2010: 209). Za promatrani je prostor bio iznimno važan razvoj crne metalurgije, pogotovo u rudnicima u Čabru i Tršću, zbog čega su dolazili stručnjaci iz slovenskih mjesta poznatima po rudarstvu. Treća industrijska grana koja se počela vrlo naglo razvijati bila je drvna industrija, od početka 19. stoljeća. Upravo je njezin razvoj bio povezan sa slovenskim investitorima, vlasnicima parnih pilana i radnicima koji su svojim iskustvom utjecali na razvoj drvne industrije $u$ Gorskom kotaru (Bognar i Bognar, 2010: 214).

Već je spomenuto da su se u Čabarski kraj doseljavali stanovnici iz svih dijelova Habsburške Monarhije, što se danas dobro opaža u tradicijskim običajima $^{5} \mathrm{i}$ idiomima goranskih mjesta. Bilo je intenzivno doseljavanje stanovništva iz slovenskih krajeva, pogotovo iz onih bližih rijekama Kupi i Čabranki. U stručnoj i znanstvenoj literaturi taj je proces zabilježen prije svega od 17. do 19. stoljeća, ali se nastavio sve do danas.

Osim doseljenika u Čabarski kraj bio je velik i broj ljudi koji su odlazili. Odlasci su bili najmasovniji krajem 19. i početkom 20. stoljeća, kada mnogo ljudi odlazi u europske države, ali i na druge kontinente (pogotovo u Ameriku) te u gospodarski razvijenije dijelove Hrvatske, osobito Slavoniju (Lajić i Klempić Bogadi, 2010: 191-192).

Istraživanja su potvrdila prekogranične veze na prostoru Čabarskoga kraja, prije svega obiteljske i prijateljske prirode. One su se očuvale iz nekoliko razloga. Prvi razlog vezan je uz činjenicu da taj geografski prostor do 1991. nije bio razdijeljen kao što je danas. Granica je postojala, no ona je unutar nekadašnje Jugoslavije bila administrativne prirode i nije predstavljala fizičku prepreku pograničnom stanovništvu pri svakodnevnom suživotu. Drugi je razlog što su prirodne prepreke Kupske i Čabarske doline te udaljenost od većih središta (Rijeke, Ljubljane, Delnica i sl.) uvjetovale relativno jaku zatvorenost toga kraja (Knežević-Hočevar, 1999: 103) te su upravo zbog toga pogranična naselja i naselja pored današnje slovenskohrvatske granice bila jače i bolje povezana međusobno nego sa središtima u

Spomenut ćemo opis nošnji žena Gorskoga kotara, koje su danas, nažalost, vrlo slabo sačuvane iako se utjecaji slovenske tradicijske kulture mogu pronaći u svim sferama tradicijske kulture Gorskoga kotara. Tako je za prostor Prezida zabilježeno da je »nošnja kranjska« (Šafar, 1981: 410). Detaljniji opis narodne nošnje možemo pronaći u djelu Dragutina Hirca: »Pristarije žene nose se na slovensku: Suknje su im o modra platna, bielo ili zeleno izšarane. Glavu si pokrivaju modrim rubcem, koji vežu pod zatiljkom. Prsi im odieva bieli haljinac (haljina), sa širokim oplećkom (kratka košulja do pojasa), koji s prieda ne skapčaju, već su im prsi nešto otvorene, kao i djevojkama. Ove nose kao snjeg biele haljine, crvene, modre ili zelene pregače, a glavu pokrivaju dugim bielim rubcima« (Hirc, 1996: 91). 
matičnim državama. To je uvjetovalo povezanost stanovništva na mikrorazini (Melik, 1959: 472). Zbog te povijesne i kulturne povezanosti nema većih kulturnih ni etnografskih razlika ni u jednom od dvaju pograničnih područja (Bognar i Bognar, 2010: 216). Mostovi na Kupi i Čabranki bili su izgrađeni zbog svakodnevnih komunikacijskih potreba lokalnog stanovništva, ali su nakon osamostaljenja Republike Hrvatske i Republike Slovenije uglavnom postali žarište problemâ. Ta je svakodnevna povezanost, rodbinska i prijateljska isprepletenost pograničnog stanovništva vidljiva i iz podataka dobivenih pregledavanjem stališa duša Čabarskoga kraja.

O doseljavanju stanovništva u Čabarski kraj pisalo se, ali ne s aspekta zabilješki u knjigama Stanje duša. Postavlja se pitanje je li moguće iz njih dobiti uvid u ukupno doseljavanje, odnosno prikazuju li one stvarno stanje. Do sada su razlozi doseljavanja dolazili do izražaja samo kod onih pojedinaca koji su svojim radom ili položajem bili prisutni u javnom životu (političari, umjetnici i dr.). U zabilješkama u knjigama Stanje duša mogu se vidjeti razlozi dolaska drugih pojedinaca koji bi inače ostali nepoznati, odnosno iz tih je podataka moguće analizirati doseljavanje i na mikrorazini, što dovodi do saznanja o lokalnoj povijesti. ${ }^{6}$

U radu se želi pokazati da su knjige Stanje duša važan izvor u povijesnim znanostima, ${ }^{7}$ kao i u mnogim drugim. Želi se upozoriti i na posebne povijesne veze između mjesta Čabarskoga kraja (Čabar, Gerovo, Plešce, Prezid i Tršće) te njihovu povezanost sa susjednim mjestima u današnjemu slovenskom pograničnom prostoru i rjeđe s udaljenijim slovenskim mjestima. ${ }^{8}$

6 Župnici su najčešće zapisivali pojedinosti, tako da se iz toga može razabrati jesu li pojedinci dolazili zbog posla, obiteljskih veza (ženidbenih veza, osnivanja obitelji) ili nečeg drugog. Osim o pojedincima postoje podaci i o doseljavanju cijelih obitelji, iako je to znatno rjeđe.

7 Matične knjige u užem smislu zastupljene su u istraživanjima te prepoznate kao važan i vjerodostojan izvor podataka u različitim znanostima. Upotrebljavaju ih povjesničari, etnolozi, antropolozi i znanstvenici drugih grana (Balkovec, 2003; Šövegeš Lipovšek, 2001; Bertoša, 2000, 2001; Pavlin, 1997; Radovanovič, 1992a; Radovanovič, 1992b i dr.). Povijesni pregled sačuvanih matičnih knjiga na prostoru današnje Hrvatske sadržava knjiga Povijesna demografija Hrvatske (Stipetić i Vekarić, 2004: 28-33). Knjiga Stanje duša postala je popularna nešto kasnije, ali je svejedno uključena u različita znanstvena djela koja se bave povijesnom demografijom (Ravnik, 1996, 1997: 28-29; Hudales, 1997; Munić, 1996/1997; Senčić, 2000; Čavrak, 1999; Žigulić, 2008).

8 U ovom smo radu preuzeli model migracija koji je razvila V. Kržišnik-Bukić, koja se i najviše bavila doseljavanjem slovenskog stanovništva u Hrvatsku. Evidentirala je najvažnije uzroke doseljavanja koji su i danas prisutni u doseljavanju slovenskog stanovništva u Hrvatsku, iako su kroz povijesna razdoblja varirali. Piše: »...v najširšem smislu zaradi zaslužka oz. službe; drugi vzrok je zgodovinsko dejstvo bega pred fašistično Italijo po prvi svetovni vojni oz. preganjanje in deportacija s strani Nemčije v času druge svetovne vojne; (...) vzpostavljanje zakonskih zvez Slovencev in Slovenk s prebivalkami in prebivalci Hrvaške; študij in šolanje sploh; selitev Slovencev po upokojitvi v obmorske kraje 
Podaci izneseni u ovom radu prikupljeni su iz knjiga Stanje duša koje se čuvaju u župnim uredima, a njihovi se mikrofilmovi nalaze u Državnom arhivu u Rijeci. Potrebno je napomenuti da matične knjige za župu Sv. Hermagora i Fortunata $\mathrm{u}$ Gerovu ne postoje jer su spaljene u Drugome svjetskom ratu, pa se ta mjesta gerovske župe spominju samo usputno. ${ }^{9}$

Za župu Sv. Antuna Padovanskog u Čabru pregledane su knjige Stališ duša I (DAR, DVD 04, ZM-34J-208) i Stališ duša župe Čabar (DAR, DVD 04, ZM-34J-208), koje obuhvaćaju početak 20. stoljeća.

Za župu Presvetog Trojstva u Plešcu pregledana je samo knjiga Status animarum XIX-XX (DAR, DVD 5, ZM-34J/214) ${ }^{10}$, u kojoj su zabilježeni podaci od sredine 19. do početka 20. stoljeća.

Za župu Sv. Vida mučenika u Prezidu pregledana je knjiga Stališ duša župe Prezid, koja obuhvaća razdoblje do tridesetih godina 19. stoljeća do sedamdesetih godina 20. stoljeća (DAR, DVD 05, ZM-34J-214).

Za župu Sv. Andrije u Tršću pregledane su dvije knjige, Stališ duša župe Tršće (DAR, DVD 5, ZM34J-215) i Status animarum 1935-1978 (DAR, DVD 5, ZM34J-215; ZM34J-216) za razdoblje od osamdesetih godina 19. stoljeća do sredine 20. stoljeća.

Pri pregledu knjiga zabilježeni su oni pojedinci kojima je kao mjesto rođenja zapisano neko slovensko mjesto ili slovenska župa. Zabilježene su i osobe za koje nije bilo zapisano mjesto rođenja ili mjesto odakle su došle, a pisalo je da su Kranjac ili Slovenac. Takvih je slučajeva bilo vrlo malo. Uzeti su u obzir i pojedinci za koje je bio zabilježen povijesni naziv prostora odakle su došli (Kranjska). Zapisani su i muškarci i žene.

U pregledanim knjigama Stanje duša iznimno je rijetko zabilježeno kada se netko doselio te se stoga za vremenski pregled doseljavanja uzimala godina vjenčanja. Ako nije bila riječ o dolasku zbog sklapanja braka, uzeta je godina zabilježena kao godina dolaska. Često u tim knjigama ne piše vrijeme dolaska, pa su kronološke dimenzije doseljavanja stanovništva slabije analizirane jer nije bila moguća detaljnija analiza. To otvara i pitanje o sta-

na Hrvaškem« (Kržišnik-Bukić, 1994/1995: 92). Prvi je razlog preuzimanja njezina modela taj što su teorijske podjele uzroka migracije preopćenite za konkretni primjer Čabarskoga kraja, koji poput svih drugih ima svoje lokalne i kulturno-političke specifičnosti. Drugi je razlog taj što se rad isključivo bavi doseljavanjem stanovništva s prostora današnje Republike Slovenije u Hrvatsku, a njezini su uzorci prilagođeni upravo takvu obliku migracije.

9 Gerovo je skoro cijelo izgorjelo 19. travnja 1945., kada je bombardirano. Tada je izgorio i župni stan sa svim matičnim knjigama i knjigama Stanje duša gerovske župe (Malnar, 2010: 57).

10 To je i jedina knjiga iz župe Plešce koja je mikrofilmirana u Državnom arhivu u Zagrebu, što znači da druge knjige te župe nisu sačuvane, odnosno potvrdu o njihovu postojanju nismo našli. 
vovima župnika koji su vodili knjige u župama Čabarskoga kraja te jesu li zapisivali sve dolaske i odlaske svojih župljana. I to znatno utječe na ovdje izneseni broj doseljenika iz današnjih slovenskih krajeva.

Podaci prikupljeni prema iznesenome modelu prikazani su posebno za svaku župu, koje su poredane abecednim redom.

Izvor podataka bile su i matične knjige učenika (matice učenika) osnovne škole $u$ Prezidu i osnovne škole $u$ Čabru. U njih se upisuju podaci o djetetu, ali i o roditeljima, njihovu zaposlenju te razlozima eventualnoga naknadnog dolaska u školu ili odlaska iz nje. Za neku je djecu nakon Drugoga svjetskog rata zapisana i nacionalnost, iako je ta rubrika upitna jer su na različitim mjestima za istu djecu zapisane različite nacionalnosti. Podaci dobiveni iz tih knjiga nisu reprezentativni i mogu samo ilustrirati situaciju zabilježenu pregledom drugih izvora. Jasno je da oni doseljenici ili iseljenici koji nisu imali djecu školske dobi nisu zabilježeni u tim knjigama. Podaci dobiveni iz njih upućuju na neke procese koji dosad nisu bili evidentirani u znanstvenoj literaturi.

\section{ŽUPA SV.ANTUNA PADOVANSKOG U ČABRU}

Središte župe Sv. Antuna Padovanskog nalazi se u Čabru, ${ }^{11}$ mjestu koje je počelo dobivati na važnosti u 17. stoljeću, kada su zaslugom Petra Zrinskog otvorene talionica željeza i kovačnica. Kada su u Čabarskom kraju otkrili željeznu rudaču, u 16. i 17. stoljeću počeli su se doseljavati pojedinci iz rudarskih krajeva, prije svega iz zapadnih dijelova Slovenije (Bohinj, Železniki i Idrija) (Blaznik, 1979; Laszowzki, 1923: 44). Danas je Čabar kulturno i upravno središte gdje se osjećaju posljedice relativno jake depopulacije, koja još uvijek traje.

Čabarska župa Sv. Antuna Padovanskog ${ }^{12}$ smještena je u pograničnom prostoru. Osnovao ju je 1663. Petar Zrinski. Matične knjige ${ }^{13}$ vode se od 1716. Pod novoosnovanu župu došao je dio krajeva koji su do tada bili pod gerovskom župom i župom u Starom Trgu (Malnar, 2008: 180-181).

Knjiga Stališ duša I (DAR, DVD 04, ZM-34J-208) restaurirana je. Podaci su upisivani na hrvatskom jeziku. Zabilježeni su ime mjesta i brojevi kuća u

11 Danas mjestima župe Sv. Antuna Padovanskog upravlja župnik iz župe Presveto Trojstvo u Plešcu.

12 U Stanju duša zapisana su sljedeća mjesta: Gornji Žagari, Gorači, Čabar, Tometi, Loknari, Tropeti, Košorogi, Tuški i Janeši.

13 Sačuvane su mnoge knjige župe Čabar, a u Državnom arhivu u Rijeci u digitaliziranom se obliku nalaze knjiga krštenih od 1716. do 1772. i od 1882. do 1814., knjiga vjenčanih od 1707. do 1765., knjiga umrlih od 1707. do 1785., Stanje duša za 19. stoljeće i dvije knjige Stanje duša za 19. i 20. stoljeće. 
kojima su živjeli ljudi čiji su podaci upisivani. Knjiga, iako ima mnogo podataka, ispunjavana je neuredno i bez kontinuiteta. Prilikom doseljavanja pojedinaca iz slovenskih mjesta nije zapisano ime mjesta, već župa odakle su došli te je obvezno dodana i pokrajina (Kranjska i sl.). Obuhvaćeno je 19. i 20. stoljeće.

Druga knjiga Stališ duša župe Čabar (DAR, DVD 04, ZM-34J-208) obuhvaća razdoblje od početka do sredine 20. stoljeća. Podaci su upisivani na hrvatskom jeziku, a zabilježene su obitelji koje su živjele u Čabru, Gornjim Žagarima, Loknarima i Pargu. Zabilješki je malo, mnogo je praznih stranica, a rubrika »Opaske« jako je oskudno ispunjena.

Osim iz slovenskih mjesta ljudi su se doseljavali i iz okolnih manjih goranskih mjesta, Hriba, Gerova, Crnog Luga, Vrbovskog, Ogulina, Tršća i drugih. Mnogo se ljudi iselilo, prije svega u obližnja hrvatska mjesta, a odlazili su i u druge hrvatske krajeve (npr. Slavoniju), vjerojatno kao i ostali stanovnici prekograničnih prostora koji su odlazili u Slavoniju raditi kao šumski radnici. ${ }^{14}$ Stanovništvo se iseljavalo u Ameriku i Italiju.

U mjesta u župi Čabar doseljavale su se osobe iz različitih slovenskih mjesta. U knjigama Stanje duša zabilježeno je 48 osoba koje su se doselile na prostor čabarske župe i 55 koje su se odselile u slovenska mjesta.

Iz tablice 1 vidljivo je da se na prostor čabarske župe doselilo 48 ljudi iz različitih slovenskih mjesta. Najviše ih se doselilo iz obližnjih mjesta i sela uz današnju hrvatsko-slovensku granicu. Činjenica da se nitko nije doselio iz Ljubljane govori o udaljenosti mjesta od većih središta te njegovoj nedostupnosti. Analizom mjesta odakle su se pojedinci doselili nije zabilježena neka posebna povezanost između tih mjesta i mjesta na prostoru čabarske župe, osim Podplanine, odakle se doselio veći broj ljudi. To je i očekivano

14 Stanovnici današnjega slovenskog prostora bolje su životne uvjete tražili i u Slavoniji. Odlazili su na sezonske poslove, i to uglavnom zimi, gdje su radili u slavonskim šumama. Poznato je da su odlazili i na prostor Ugarske te u Rumunjsku. Zvali su ih hrvatarji. Danju su obrađivali drvo, a noću spavali u zajedničkim kolibama. Smatra se da su ih zvali hrvatarji jer su odlazili na posao na prostor današnje Hrvatske te se odatle vraćali kući. U vrijeme veoma jakog iseljavanja u slovenskim se novinama mogu pronaći različiti agitacijski tekstovi kojima se pozivalo na odlazak u Slavoniju, a ne u Ameriku (Drnovšek, 1995: 107-113). Vera Kržišnik-Bukić smatra da je to iseljavanje, sezonsko ili agrarno, bilo djelomično planirano. To su uglavnom bile skupine od šest do četrnaest ljudi iz Notranjske, odnosno od trideset do pedeset ljudi iz Dolenjske. Većinom su to bili siromašni seljaci koji su nakon završenih radova na polju, od listopada do travnja, organizirano odlazili na rad u Slavoniju (Kržišnik-Bukić, 1995: 136-137). Posao je bio vrlo težak, ponekad su radili i po osamnaest sati dnevno. Kada muška radna snaga više nije bila dostatna, na rad u Slavoniju i Bačku odlazile su i žene iz Prekmurja (Kuzmič, 1995). Na sezonski su posao išle i šesnaestogodišnjakinje. Bile su slabije plaćene te su ih slabije hranili. Primjerice za dvomjesečni su rad žene i mlađi muškarci (do osamnaeste godine) dobivali $450 \mathrm{~kg}$ žita, a odrasli muškarci 600 kg (Drnovšek, 2012: 136). 
jer je posrijedi slovensko mjesto koje je najbliže gradu Čabru, od kojega je udaljeno $2,5 \mathrm{~km}$. Jedini su razlozi dolazaka bili osobne i obiteljske prirode, odnosno zbog vjenčanja; za dvije doseljene obitelji razlog dolaska nije zabilježen. Obitelji su došle iz slovenskih mjesta Draga i Babno Polje. Možemo pretpostaviti da su došle radi boljih životnih uvjeta.

Tablica 1. Doseljenici na prostor župe Sv. Antuna Padovanskog u Čabru prema mjestu odakle su doselili

Table 1. Immigrants in the area of St. Anthony of Padua Parish in Čabar, by place of emigration

\begin{tabular}{lc||lc}
\hline Slovenska mjesta & $\begin{array}{c}\text { Broj } \\
\text { doseljenika }\end{array}$ & Slovenska mjesta & $\begin{array}{c}\text { Broj } \\
\text { doseljenika }\end{array}$ \\
\hline Babno Polje & 5 & Nova Vas & 1 \\
\hline Bloke & 1 & Novi Kot & 2 \\
\hline Brezovica & 1 & Osilnica & 5 \\
\hline Cerknica & 1 & Podplanina & 8 \\
\hline Črni Potok & 5 & Senožeče & 1 \\
\hline Črnomelj & 1 & Sinji Vrh & 1 \\
\hline Draga & 2 & Sodražica & 4 \\
\hline Kal & 1 & Stari Kot & 1 \\
\hline Kočevje & 1 & Trava & 1 \\
\hline Koper & 1 & Žlebič & 2 \\
\hline Logatec & 1 & Žurge & 48 \\
\hline Mlaka & 1 & Ukupno & \\
\hline$*$
\end{tabular}

* Sinji Vrh pri Črnomlju nalazi se u pograničnom pojasu, ali ne graniči s promatranim prostorom te se zato ovdje ne tretira kao pogranično mjesto.

Na prostor čabarske župe doselile su se 32 žene i 16 muškaraca. Neki su se vjenčali u slovenskome mjestu odakle je dolazila djevojka, a potom se preselili u mjesta čabarske župe; postoje četiri takva zabilježena primjera, iako ih je možda bilo i više.

Najviše je ljudi došlo do 1918., njih 31. Između dva svjetska rata doselilo se osmero ljudi, a nakon Drugoga svjetskog rata devetero.

Broj ljudi koji su se s prostora čabarske župe odselili u slovenske krajeve veći je od broja doseljenika. Podaci su navedeni u tablici 2. 
Tablica 2. Iseljenici koji su odselili s prostora župe Sv. Antuna Padovanskog u Čabru u slovenska mjesta

Table 2. Emigrants who moved from the area of St. Anthony of Padua Parish in Čabar to Slovenian settlements

\begin{tabular}{lc||lc}
\hline Slovenska mjesta & $\begin{array}{c}\text { Broj } \\
\text { iseljenika }\end{array}$ & Slovenska mjesta & $\begin{array}{c}\text { Broj } \\
\text { iseljenika }\end{array}$ \\
\hline Adlešiči & 1 & Novo Mesto & 1 \\
\hline Babno Polje & 3 & Osilnica & 1 \\
\hline Črni Potok & 7 & Rakek & 1 \\
\hline Domžale & 1 & Podplanina & 8 \\
\hline Draga & 1 & Stari Kot & 1 \\
\hline Kočevje & 10 & Stari Trg & 2 \\
\hline Koroška Bela & 1 & Trava & 1 \\
\hline Litija & 1 & Velike Lašče & 1 \\
\hline Ljubljana & 5 & Vrh & 1 \\
\hline Logatec & 1 & Slovenija & $\mathbf{5 1}$ \\
\hline Loški Potok & 2 & Ukupno & 1 \\
\hline
\end{tabular}

Osim vjenčanja nije naveden nijedan drugi podatak koji bismo mogli navesti kao razlog odlaska iz župe u slovenske krajeve. Iz tih krajeva nisu odlazile cijele obitelji, samo pojedinci. Na temelju toga možemo zaključiti da se u Sloveniju udala 31 žena, a oženilo se dvadeset muškaraca. Najviše je ljudi otišlo nakon Drugoga svjetskog rata, dvadeset dvoje. Između dva svjetska rata otišlo je dvanaestero ljudi, a prije 1918. zabilježen je odlazak šestero ljudi. Za njih jedanaestero nije zabilježeno vrijeme odlaska.

Broj žena koje su se doselile ili odselile veći je nego broj muškaraca. Zabilježene su 63 žene (od toga su 32 došle i 31 je otišla) te 36 muškaraca (šesnaest ih je došlo i dvadeset otišlo). Razlozi dolaska i odlaska uglavnom su bili osobni i obiteljski.

Činjenica da je broj odseljenih veći od broja doseljenih ne čudi. To je proces koji susrećemo i u drugim mjestima župa Čabarskoga kraja, primjerice u prezidskoj župi, gdje je to izraženije.

Valja napomenuti da je vrijeme odlaska ljudi iz Slovenije različito, dok su, po svemu sudeći, razlozi odlaska isti. Ako se uspoređuju razdoblja odla- 
ska i dolaska pojedinaca, vidi se da su obrnuto proporcionalna. Naime dok je najviše ljudi došlo u Čabarski kraj prije 1918., u tom je razdoblju njih najmanje otišlo (šestero). Nakon Drugoga svjetskog rata na prostor čabarske župe došlo je samo devetero ljudi, a otišlo njih dvadeset dvoje.

Iz matičnih knjiga učenika u osnovnoj školi u Čabru ${ }^{15}$ vidi se da su osim trajnih migracija, o kojima smo dosad pisali, postojale i dnevne migracije, $\mathrm{i}$ to s prostora današnje Republike Slovenije u Hrvatsku. Tu je prije svega riječ o učenicima koji su živjeli u mjestima blizu današnje slovensko-hrvatske granice te svaki dan dolazili u školu u Čabar. Te dnevne migracije vidljive su kod djece koja su živjela u naseljima Podplanina, Črni Potok i Trava. Odlaske u osnovnu školu u Čabar opisala je nekadašnja učenica koja je živjela u Podplanini. Sjeća se da su neka djeca iz njezina mjesta odlazila u školu u mjestu Trava, a neka u Čabar. Odluku gdje će se djeca školovati donosili su njihovi roditelji (R. K., Čabar, 2006). ${ }^{16}$

Dnevne migracije i odlasci u školu samo su jedan od pokazatelja povezanosti žitelja s obje strane današnje hrvatsko-slovenske granice. Na promatranom su prostoru sigurno postojali i drugi svakodnevni oblici dnevnih migracija (posjet članovima šire obitelji, odlazak na posao, odlazak u crkvu, k liječniku i sl.), koji su bili uvjetovani isključivo odlukama pojedinaca. Ovdje prikazani procesi doseljavanja, ali i dnevnih migracija na prostoru čabarske župe slični su kao i na prostorima drugih župa Čabarskoga kraja.

\section{ŽUPA PRESVETOG TROJSTVA U PLEŠCU}

Središte je župe Presvetog Trojstva u mjestu Plešce, koje je bilo važno sjecište puteva. U njemu se pretovarivala roba koja je trgovačkim putem uz Kupu bila namijenjena za transport u smjeru Prezida i Gerova ili Čabra. Po navodima nekih autora, Plešce je svoje zlatno doba doživjelo krajem 19. stoljeća, kada je imalo oko 1600 stanovnika. Izgradnja ceste uzrokovala je slabljenje položaja toga mjesta jer je Čabar tada preuzeo ulogu centralnog naselja Čabarskoga kraja (Smole, 2006). ${ }^{17}$

15 Pregledane su knjige Glavni imenici 1943./1944., 1947./1948., Glavni imenik od 1945./1946. do 1953./1954. godine, Dnevnik, imenik, 1954/1955-1959/1960, Matična knjiga Čabar I od 7. 1. 1960 do 30. 6. 1964. te Matična knjiga 3. Broj knjiga koje se danas čuvaju u osnovnoj školi u Čabru nije velik jer je dio njih spaljen u Drugome svjetskom ratu.

16 Zbog anonimnosti informatora ovdje su dani samo inicijali. Sve podatke ima autorica rada.

17 O važnosti mjesta Plešce kao trgovačkog središta svjedoči i priča o obitelji Čop. Obiteljsko ime obitelji Cop glasi Palčavi, doselili su se iz Babnog Polja, prema nekim informacijama već 1856. (Smole, 2005: 128). Već iz prethodnih razdoblja postoji veza s mjestom jer su u njemu imali posjed i dok su još stanovali u Babnom Polju (Smole, 2006: 227). Danas je njihova kuća etnološka zbirka »Palčava šiša«. U kući su predstavljeni život bogatog 
Župa Plešce osnovana je 1807. (Kovač, 1993: 201). Pregledana knjiga Status animarum XIX-XX (DAR, DVD 5, ZM-34J/214) ima malo zapisanih podataka i opaski. Pisana je na hrvatskom jeziku, a podaci su zabilježeni za razdoblje od sredine 19. do sredine 20. stoljeća. U Stanju duša zabilježene su samo tri osobe koje su došle u Plešce iz slovenskih krajeva. Jedna je došla iz Celja, jedna iz Pivke i jedna iz Ljubljane. Nijedna nije došla iz pograničnog prostora, već su se doselile iz većih slovenskih gradova. Riječ je o dvama muškarcima i jednoj ženi. Sve troje doselilo se u šezdesetim godinama 20. stoljeća. Može se zaključiti da su razlozi dolaska bili privatne, odnosno obiteljske naravi. Da je knjiga Stanje duša starija te da je bolje popunjena, vjerojatno bi u njoj bio zabilježen i veći broj ljudi koji se doselio na prostor župe Plešce ili se s njega odselio te bi se potpunije prikazale veze između slovenskih i hrvatskih mjesta.

\section{ŽUPA SV.VIDA MUČENIKA U PREZIDU}

Mjesto Prezid središte je župe Sv. Vida mučenika. Naselje se nalazi na samoj granici s Republikom Slovenijom. Ime Prezid dobilo je 1725., do kada se zvalo Altbabenfeld, odnosno Staro Babno Polje. Život u tim krajevima potaknuli su kneževi Frankopani i Zrinski. Zabilježeno je da je 1850. Prezid imao 1525 stanovnika (Wolf, 2006: 12-13). Vidljiva je posebna povezanost Prezida i susjednih slovenskih mjesta. Stanovništvo se odseljavalo u njih, ali su i mnogi iz tih slovenskih mjesta dolazili u Prezid. Dio doseljenog stanovništva vjerojatno je došao i zbog vrlo važne drvne industrije u Prezidu, koju je potaknula obitelj Vilhar. ${ }^{18}$

Danas je to župa koja sa sve tri strane graniči s Republikom Slovenijom. Osnovana je 1807., kao i većina goranskih župa (Kovač, 1993: 308). Od župnih knjiga pregledana je samo jedna knjiga Stanje duša. Na prvoj desnoj stranici knjige pod imenom Stališ duša župe Prezid piše: »Stališ duša prepisan iz općine Prezid- stališ duša- U Prezidu 27. II. 1916.« Na dnu stranice

gospodarstva iz sredine 19. stoljeća te život i kultura ljudi iz doline Čabranke. Na posjedu su sačuvani stara trgovina s originalnom opremom, nadsvođene prizemne prostore $s$ prezentacijom gostionice, a na katu stara kancelarija, salon s bogatom opremom i dekoracijom iz osamdesetih godina 19. stoljeća te spavaće sobe. Mogu se pogledati i etnografska zbirka, tavan i nadsvođeni podrumi nekadašnje veletrgovine vinom. Kući pripada i gospodarska zgrada, jedina takva potpuno kamena zgrada u dolini.

18 Obitelj Vilhar posjedovala je parnu pilanu u Prezidu, koja je počela s radom 1849. i bila jedna od prvih na području Gorskoga kotara te u Hrvatskoj uopće. Aleksandar Vilhar (1813. - 1868.) bio je rodom iz Planine kod Rakeka. Naslijedio ga je sin Ščitomir Vilhar (1840. - 1904.), a njegov sin Dušan (1867. - 1913.) izgradio je 1902. parnu pilanu u Gerovu (Malnar, 2008: 159). On se poslije, kao veletrgovac drvima i posjednik, preselio na Sušak, gdje je utemeljio samostalnu tvrtku Dušan Vilhar sa skladištem na Delti (Lukežić, 2007: $59)$. 
potpisan je tadašnji župnik Kauzlarić, koji je u župi djelovao od 1914. do 1933. (DAR, DVD 05, ZM-34J-214, MO 1806447).

Na početku knjige nalazi se popis obitelji na prostoru župe Prezid. Knjiga je pisana na hrvatskom jeziku, numerirana je ručno, a zapisani su i brojevi kuća. Stanje duša bogato je ispunjeno, mnogim podacima, i stoga se može zaključiti da je prepisano. To nam potvrđuje i zapis tadašnjeg župnika Kauzlarića, koji je vjerojatno tu knjigu prepisao te je dopunio podacima do kojih je mogao doći. Zabilješke obuhvaćaju razdoblje od tridesetih godina 19. stoljeća do sedamdesetih godina 20. stoljeća. Nije bilo moguće pročitati sve podatke jer su neki napisani nečitljivo, na marginama.

Zabilježeno je sedamdesetero ljudi koji su se iz slovenskih mjesta doselili na prostor župe Sv. Vida mučenika. Za njih 149 zabilježeno je da su otišli u slovenska mjesta.

Podaci o tome koliko se ljudi doselilo i iz kojih krajeva navedeni su u tablici 3.

Tablica 3. Doseljenici na prostor župe Sv. Vida mučenika u Prezidu prema mjestu odakle su doselili

Table 3. Immigrants in the area of St. Vitus the Martyr Parish in Prezid, by place of emigration

\begin{tabular}{lc|lc}
\hline Slovenska mjesta & $\begin{array}{c}\text { Broj } \\
\text { doseljenika }\end{array}$ & Slovenska mjesta & $\begin{array}{c}\text { Broj } \\
\text { doseljenika }\end{array}$ \\
\hline Babno Polje & 14 & Radlek & 1 \\
\hline Cerknica & 1 & Ravne & 2 \\
\hline Dolenje Poljane & 2 & Ribnica & 1 \\
\hline Goče & 1 & Rogatec & 1 \\
\hline Gorica & 1 & Sodražica & 1 \\
\hline Iga Vas & 2 & Srednja Vas-Loški Potok & 1 \\
\hline Knežja Njiva & 1 & Stari trg & 3 \\
\hline Loški Potok & 4 & Trava & 1 \\
\hline Novi Kot & 21 & Vrhnika & 3 \\
\hline Osilnica & 2 & Žiri & 1 \\
\hline Podgorje & 1 & Žurge & 1 \\
\hline Podpreska & 2 & Kranjska & 69 \\
\hline & & Ukupno &
\end{tabular}


Kao što je vidljivo iz tablice 3, na prostor župe u Prezidu doseljavale su se osobe iz cijelog prostora današnje Republike Slovenije. Za jednu je osobu župnik zabilježio samo povijesni naziv pokrajine i da se doselila iz Kranjske (DAR, DVD 05, ZM-34J214: MO 1806480). Najviše je ljudi, njih 53, došlo iz pograničnog prostora, iz mjesta u neposrednoj blizini današnje slovensko-hrvatske granice. Tako je 21 osoba došla iz Novega Kota, a trinaest iz Babnoga Polja. Prezid i oba mjesta udaljeni su manje od tri kilometra, što je sigurno utjecalo na relativno veliki broj doseljenika. Iz ostalih je pograničnih mjesta broj doseljenika bio manji.

Razlozi navedeni u Stanju duša za doseljenje 53 žene i 16 muškaraca uglavnom su osobne i obiteljske prirode, odnosno došli su zbog vjenčanja. No bilo je i onih koji su se na taj prostor doselili iz drugih razloga. Valja spomenuti svećenika Franju Poša (Wolf, 2006: 22), ${ }^{19}$ koji je 1939. iz Rogateca premješten u Prezid, gdje je postao župnikom. Tu je funkciju obavljao od 1939. do 1944. (DAR, DVD 05, ZM-34J214: MO 1806472).

Kada govorimo o vremenu doseljavanja, vidljivo je da su se samo četiri osobe doselile do 1918. Između dva svjetska rata doselilo se 47 osoba, nakon 1945. doselilo ih se trinaest. Za pet osoba nije zabilježeno vrijeme dolaska.

Kao jedan od razloga što je zabilježeno toliko malo doseljenika do 1918. možemo navesti činjenicu da je knjiga prepisana i da u nju možda nisu bili uneseni svi podaci, odnosno župnik ih nije znao. Moguće je i da zbog neažurnosti župnika prije 1914. nisu bili upisani svi koji su došli na prostor župe Sv. Vida mučenika.

Važno je napomenuti i da se s prostora župe u Prezidu, prema podacima iz Stanja duša, iselilo 149 osoba. U tablici 4 navedeno je u koja su se slovenska mjesta ljudi iseljavali.

19 Prezidski je svećenik Franjo Poš, između ostaloga, bio i član Okrajnega odbora Osvobodilne fronte za Prezid tijekom listopada 1941. (Petešić i Bilandžić, 1982: 25). Franjo Poš nije bio jedini svećenik rođen u Sloveniji koji je djelovao u župama Gorskoga kotara. Valja spomenuti veći broj župnika koji su djelovali na prostoru župa Čabarskoga kraja, a rođeni su u slovenskim mjestima. Jakov Amstadt djelovao je kao župnik u Tršću, a u Gerovu je naslijedio J. Matijevića (Kovač, 1993: 21-22). Julij Kessler rođen je u Borovnici 1904., a između ostaloga je djelovao u Prezidu i Čabru (Valenčič, 2010: 14). U župi Plešce djelovao je od 1948. do 1968. župnik Karlo Požun (Kovač 1993: 19). Janko Weingerl rođen je u Zgornjem Korenu (Sv. Barbara), a funkciju župnika u Prezidu obavljao je od 1950. do 1960. (Wolf, 2006: 22). 
Tablica 4. Iseljenici koji su odselili s prostora župe Sv. Vida mučenika u Prezidu u slovenska mjesta

Table 4. Emigrants who moved from the area of St. Vitus the Martyr Parish in Prezid to Slovenian settlements

\begin{tabular}{lc|lc||lc}
\hline $\begin{array}{l}\text { Slovenska } \\
\text { mjesta }\end{array}$ & $\begin{array}{c}\text { Broj } \\
\text { iseljenika }\end{array}$ & $\begin{array}{l}\text { Slovenska } \\
\text { mjesta }\end{array}$ & $\begin{array}{c}\text { Broj } \\
\text { iseljenika }\end{array}$ & $\begin{array}{l}\text { Slovenska } \\
\text { mjesta }\end{array}$ & $\begin{array}{c}\text { Broj } \\
\text { iseljenika }\end{array}$ \\
\hline Ajdovščina & 1 & Ilirska Bistrica & 2 & Predloka & 2 \\
\hline Babno Polje & 29 & Izola & 1 & Pudob & 2 \\
\hline Banja Loka & 1 & Kočevje & 22 & Ribnica & 1 \\
\hline Bled & 1 & Kranj & 1 & Sladka Gora & 1 \\
\hline Bloke & 1 & Loški Potok & 4 & Stara Cerkev & 2 \\
\hline Brezovica & 1 & Lož & 2 & Stari Kot & 1 \\
\hline Celje & 3 & Ljubljana & 15 & Stari Trg & 9 \\
\hline Cerknica & 3 & Mengeš & 2 & Trava & 1 \\
\hline Dobro Polje & 1 & Mozelj & 3 & Tržič & 1 \\
\hline Dolenja Vas & 1 & Novi Kot & 20 & Velike Lašče & 1 \\
\hline Donji Logatec & 1 & Osilnica & 2 & Vipava & 1 \\
\hline Draga & 7 & Podplanina & 1 & Vrhnika & 2 \\
\hline & & & & Ukupno & $\mathbf{1 4 9}$ \\
\hline & & & & & \\
\hline
\end{tabular}

Kao što je vidljivo iz tablice 5, s prostora župe u Prezidu iselilo se 149 osoba. Mnogo ih je otišlo u mjesta na pograničnom prostoru. Najviše ih se iselilo u Babno Polje.

Odselilo se 99 žena i 50 muškaraca. Za 69 osoba vrijeme odlaska nije zabilježeno. Do 1918. iselilo se 26 osoba, između dva svjetska rata otišlo ih je devetnaest, a nakon Drugoga svjetskog rata 35.

Razlozi odlaska nisu zabilježeni kod svih pojedinaca. Za 96 njih zapisano je da su se vjenčali u slovenskim mjestima, tako da možemo zaključiti da su ljudi uglavnom odlazili zbog osobnih i obiteljskih razloga, ali neki i zbog drugih, prije svega lakšeg zapošljavanja ili nekih ovdje nezabilježenih. Vjerojatno je bilo i iseljavanja cijelih obitelji.

Kao i u župi Sv. Antuna Padovanskog i ovdje su razdoblja doseljavanja i odseljavanja obrnuto proporcionalna. Tako je najviše doseljenika (47) zabilježeno upravo između dva svjetska rata, kada je bilo i najmanje odseljavanja (19). 
Neke ovdje navedene tvrdnje, primjerice iseljavanje cijelih obitelji, možemo potkrijepiti i podacima iz knjiga učenika osnovne škole u Prezidu. ${ }^{20}$ Relativno mnogo djece nastavilo je školovanje u Sloveniji, što znači da se određeni broj ljudi odselio s obiteljima u Sloveniju. Razlozi tih odlazaka nisu naznačeni, ali se može zaključiti da su odlazili zbog boljih životnih uvjeta. Za neke je učenike zapisano da su se neko vrijeme školovali u Sloveniji te se poslije vratili, a za druge da su roditelji dobili posao u slovenskih mjestima. To potkrepljuje pretpostavku da su odlasci bili potaknuti i višim životnim standardom obitelji u susjednom kraju ili većom mogućnošću zapošljavanja. Bilo je i slučajeva kada su djeca prekidala školovanje da bi zaradila za život. ${ }^{21}$

Relativno veliki broj djece iz slovenskih mjesta polazio je školu u Prezidu, i to uglavnom iz mjesta Podraga, Stari Kot i Novi Kot. Škola u Prezidu bila je bliža od one na slovenskoj strani. Dnevne migracije djece zabilježene su nakon Drugoga svjetskog rata, od 1948. do sedamdesetih godina.

Valja naglasiti i da su žene iz Čabarskoga kraja, prije svega s prostora Prezida, odlazile rađati u bolnicu u Postojni. Odlasci u zdravstvene ustanove u Sloveniju prestali su $1991 .^{22}$

Na prostoru župe Sv. Vida mučenika zabilježeni su različiti procesi doseljavanja i iseljavanja stanovništva, ali i dnevnih migracija, koje je moguće uočiti i u drugim mjestima pograničnih župa.

\section{ŽUPA SV.ANDRIJE U TRŠĆU}

Središte župe Sv. Andrije jest mjesto Tršće, naselje koje danas poprima karakteristike turističkog mjesta. Postanak mjesta povezuje se s početkom iskorištavanja željezne rude i izgradnjom čabarske željezare (Arh, 1998: 72). Od 18. stoljeća na prostoru Rudnika kopali su željeznu rudaču za čabarsku željezariju, a od početka 20. stoljeća kopala se i cibaritna rudača.

20 Osnovna škola u Prezidu bila je područna škola osnovne škole u Čabru te se tamo nalaze matične knjige koje se odnose na osnovnu školu u Prezidu. Pregledane su sljedeće knjige: Glavni imenik školskih sposobnjaka niže pučke škole u Prezidu od 1. 9. 1904., Popis školskih sposobnjaka za školsku godinu 1919./1920., Glavni imenik 2. Osnovne narodne škole Prezid od godine 1945./1946., Matična knjiga 1962./1963. od 1. do 22., Osnovna škola Prezid. Razredba knjiga osmog (VIII.) razreda za šk. godinu 1962./1963., Osnovna škola Prezid. Matična knjiga svezak 4. od 1. 9. 1962. do 30. 8. 1969. godine. Od red. broja 1. do 392., Matična knjiga Osnovne škole »Janeš Ivan « - Prezid. Svezak 5., od 1. 9. 1969. godine i od red. broja 1.

21 Valja navesti slučaj dječaka koji je napustio školu kao dvanaestogodišnjak. Tako je za H. J.-a 1932. u njegov školski imenik bilo zapisano da je otišao služiti u Podgoru.

22 To nije bio osamljeni slučaj. Žene iz pograničnog prostora u Istri odlazile su rađati u bolnicu u Kopar, dok su žene s prostora općine Ilirska Bistrica, prije svega mjesta bližih granici, odlazile rađati u bolnicu u Rijeci. 
Župa Tršće ${ }^{23}$ utemeljena je 1807., a do tada su mjesta i sela koji su pripali novoosnovanoj župi bili pod upravom župnika u Čabru. Matične knjige vode se od 1890. (Kovač, 1993: 366).

Obje knjige Stanje duša, ${ }^{24}$ Stališ duša župe Tršće (DAR, DVD 5, ZM34J-215) i Status animarum 1935-1978 (DAR, DVD 5, ZM34J-215; ZM34J-216), numerirane su. Iako su knjige stare, u njih nije zapisano mnogo podataka, te je teško razlučiti tko je došao u Gorski kotar iz današnjih slovenskih krajeva. Zbog toga je zabilježen relativno mali broj ljudi. Vidljivo je da su se u mjesta župe Tršće doseljavali ljudi i iz okolnih hrvatskih mjesta, jednako kao što su se iz njih i iseljavali. Zabilježeno je petnaest osoba koje su došle iz nekog slovenskog mjesta. Podaci su navedeni u tablici 5.

Tablica 5. Doseljenici na prostor župe Sv. Andrije u Tršću prema mjestu odakle su doselili

Table 5. Immigrants in the area of St. Andrew Parish in Tršće, by place of emigration

\begin{tabular}{lc|lc}
\hline Slovenska mjesta & $\begin{array}{c}\text { Broj } \\
\text { doseljenika }\end{array}$ & Slovenska mjesta & $\begin{array}{c}\text { Broj } \\
\text { doseljenika }\end{array}$ \\
\hline Bosljiva Loka & 1 & Podplanina & 1 \\
\hline Črni Potok & 3 & Rakek & 1 \\
\hline Iga Vas & 1 & Stari Kot & 1 \\
\hline Kočevje & 1 & Trava & 1 \\
\hline Loški Potok & 2 & Vrhnika & 1 \\
\hline Mali Log & 1 & Žurge & 1 \\
\hline \multirow{2}{*}{} & \multirow{2}{*}{} & Ukupno & $\mathbf{1 5}$ \\
\cline { 3 - 4 } & & &
\end{tabular}

Od petnaest doseljenih osoba deset su bile žene, a pet muškarci. Svi su došli zbog vjenčanja i osnivanja obitelji; u statusima nije naveden nijedan drugi razlog. Za tri je osobe zabilježeno da su došle prije Prvoga svjetskog rata. Najviše ih se doselilo između dva svjetska rata, njih jedanaest. Nije zabilježen dolazak nijedne osobe nakon Drugoga svjetskog rata. Za jednu osobu vrijeme dolaska nije zapisano.

23 Župa Tršće obuhvaća mjesta Crni Lazi, Selo, Lazi, Gorniki, Ferbežari, Makov ili Markov Hrib, Prhci, Kraljev Vrh, Prhutova Draga, Brinova Draga, Srednja Draga, Pršleti, Smrekova Draga i Zikovci (Kovač, 1993: 366).

24 Najmlađa obiteljska knjiga obuhvaća razdoblje od 1881. do 1898. 
Pojedince koji su se doselili na prostor župe Tršće spominje i Slavko Malnar. On je zapisao da se u kuću Žagarovih u Brinjevu Dragu doselio zet Lipovac te je time bilo izmijenjeno i obiteljsko ime u Kutar jer je zet došao iz Kuta (Malnar, 2010: 34). To nije jedini primjer koji navodi. Valja spomenuti i mjesto Ravnice, gdje je obitelj Benčina iz Novega Kota kupila kuću te držala konje i krave (Malnar, 2010: 77). U Gornje Vrhe u kuću Veselavi doselila su se čak dva zeta. Oba su bila iz Črnog Potoka. Ivan Lavrič doselio se 1889., a Anton Vesel, po kojem je kuća i dobila ime, 1892. (Malnar, 2010: 99).

Slabije doseljavanje u Tršće može se objasniti u prvom redu činjenicom da je ono udaljenije od slovensko-hrvatske granice. Tršće nije imalo osobito razvijenu industriju pa stoga to nije bilo mjesto u kojem bi doseljenici tražili mogućnost zaposlenja ili bolje životne uvjete. Prednost naselja u njegovu je položaju, jer se nalazi na glavnoj cesti za Gerovo, odakle se može putovati prema Delnicama i Rijeci, odnosno Zagrebu.

Iz toga proizlazi da je prostor Gorskoga kotara u stanovitoj mjeri bio poželjno mjesto za doseljavanje, ali i mjesto s kojeg su stanovnici odlazili. Radi boljeg uvida u to iz kojih su se mjesta stanovnici doseljavali i iz kojih iseljavali napravili smo komparativni prikaz svih relevantnih mjesta iz čabarske župe.

Detaljniji zabilježeni podaci za župe Čabarskoga kraja navedeni su u tablici 6.

Tablica 6. Doseljenici iz slovenskih mjesta u župe Čabarskoga kraja Table 6. Immigrants from Slovenian settlements to parishes in Čabar region

\begin{tabular}{|c|c|c|c|c|c|}
\hline \multirow{2}{*}{ Slovenska mjesta } & \multicolumn{4}{|c|}{ Hrvatske župe } & \multirow{2}{*}{ Ukupno } \\
\hline & Ž. Čabar & Ž. Plešce & Ž. Prezid & Ž. Tršće & \\
\hline Babno Polje & 5 & & 14 & & 19 \\
\hline Bloke & 1 & & & & 1 \\
\hline Bosljiva Loka & & & & 1 & 1 \\
\hline Brezovica & 1 & & & & 1 \\
\hline Celje & & 1 & & & 1 \\
\hline Cerknica & 1 & & 1 & & 2 \\
\hline Črni Potok & 5 & & & 3 & 8 \\
\hline Črnomelj & 1 & & & & 1 \\
\hline Dolenje Poljane & & & 2 & & 2 \\
\hline Draga & 2 & & & & 2 \\
\hline Goče & & & 1 & & 1 \\
\hline
\end{tabular}




\begin{tabular}{|c|c|c|c|c|c|}
\hline \multirow{2}{*}{ Slovenska mjesta } & \multicolumn{4}{|c|}{ Hrvatske župe } & \multirow{2}{*}{ Ukupno } \\
\hline & Ž. Čabar & Ž. Plešce & Ž. Prezid & Ž. Tršće & \\
\hline Gorica & & & 1 & & 1 \\
\hline Iga vas & & & 2 & 1 & 3 \\
\hline Kal & 1 & & & & 1 \\
\hline Knežja Njiva & & & 1 & & 1 \\
\hline Kočevje & 1 & & & 1 & 2 \\
\hline Koper & 1 & & & & 1 \\
\hline Kranjska & & & 1 & & 1 \\
\hline Ljubljana & & 1 & & & 1 \\
\hline Logatec & 1 & & & & 1 \\
\hline Loški Potok & & & 4 & 2 & 6 \\
\hline Mali Log & & & & 1 & 1 \\
\hline Mlaka & 1 & & & & 1 \\
\hline Nova vas & 1 & & & & 1 \\
\hline Novi Kot & 2 & & 21 & & 23 \\
\hline Osilnica & 5 & & 2 & & 7 \\
\hline Pivka & & 1 & & & 1 \\
\hline Podgorje & & & 1 & & 1 \\
\hline Podplanina & 8 & & & 1 & 9 \\
\hline Podpreska & & & 2 & & 2 \\
\hline Radlek & & & 1 & & 1 \\
\hline Rakek & & & & 1 & 1 \\
\hline Ravne & & & 2 & & 2 \\
\hline Ribnica & & & 1 & & 1 \\
\hline Rogatec & & & 1 & & 1 \\
\hline Senožeče & 1 & & & & 1 \\
\hline Sinji Vrh & 1 & & & & 1 \\
\hline Sodražica & 1 & & 1 & & 2 \\
\hline Srednja vas & & & 1 & & 1 \\
\hline Stari Kot & 4 & & & 1 & 5 \\
\hline Stari trg & & & 3 & & 3 \\
\hline Trava & 1 & & 1 & 1 & 3 \\
\hline Vrhnika & & & 3 & 1 & 4 \\
\hline Žiri & & & 1 & & 1 \\
\hline Žlebič & 1 & & & & 1 \\
\hline Žurge & 2 & & 1 & 1 & 4 \\
\hline Ukupno & 48 & 3 & 69 & 15 & 135 \\
\hline
\end{tabular}


Iz tablice 6 vidi se da se na prostor ovdje spomenutih župa Čabarskoga kraja doselilo barem 135 osoba, i to iz različitih slovenskih mjesta. Možemo zaključiti da ne postoji slovensko mjesto iz kojega su se ljudi doselili u sve četiri župe Čabarskoga kraja. U tablici se ističu mjesta odakle se doselilo desetak ili više osoba. To su uglavnom ona koja su danas najbliža slovensko-hrvatskoj granici: Novi Kot, Babno Polje, Črni Potok, Podplanina i neka druga s manjim brojem doseljenika. Vrijeme dolaska te jesu li se doseljavali iz udaljenih ili bližih mjesta te jesu li se doseljavali muškarci ili žene navedeni su u tablici 7.

Tablica 7. Doseljenici prema prostoru odlaska, spolu i vremenu dolaska u Čabarski kraj

Table 7. Immigrants in Čabar region, by departure area, gender and time of arrival

\begin{tabular}{|c|c|c|c|c|c|c|c|c|c|}
\hline \multirow[b]{2}{*}{$\begin{array}{l}\text { Župe } \\
\text { Čabarskoga } \\
\text { kraja }\end{array}$} & \multicolumn{2}{|c|}{$\begin{array}{l}\text { Prostor } \\
\text { odlaska }\end{array}$} & \multicolumn{2}{|c|}{ Spol } & \multicolumn{4}{|c|}{ Vrijeme dolaska } & \multirow[b]{2}{*}{$\frac{8}{2}$} \\
\hline & 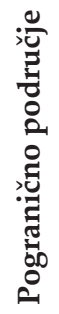 & 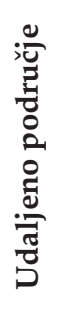 & 芯 & 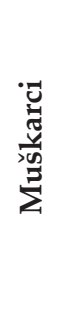 & 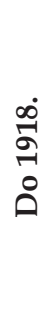 & $\begin{array}{l}\text { oे } \\
\sigma \\
0 \\
0 \\
\infty \\
\frac{0}{2} \\
\frac{1}{0} \\
0\end{array}$ & 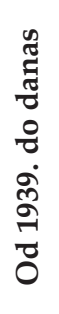 & 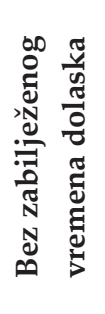 & \\
\hline Župa Čabar & 33 & 15 & 32 & 16 & 31 & 8 & 9 & - & 48 \\
\hline Župa Plešce & l & 3 & 1 & 2 & - & - & - & 3 & 3 \\
\hline Župa Prezid & 53 & 16 & 53 & 16 & 4 & 47 & 13 & 5 & 69 \\
\hline Župa Tršće & 10 & 5 & 10 & 5 & 4 & 11 & / & 1 & 15 \\
\hline Ukupno & 96 & 39 & 96 & 39 & 39 & 66 & 22 & 8 & 135 \\
\hline
\end{tabular}

U tablici 7 mjesta su podijeljena na ona u pograničnom prostoru i ona udaljenija od granice. Iz pograničnih slovenskih mjesta došlo je 96 osoba, a 39 ih je došlo iz udaljenijih krajeva. U ukupnom broju doseljenih osoba u mjesta župa Čabarskoga kraja više je žena nego muškaraca: 96 žena i 39 muškaraca. Uglavnom je bilo zabilježeno i vrijeme doseljavanja. Za 39 osoba evidentirano je da su se doselile prije kraja Prvoga svjetskog rata, 66 njih 
doselilo se između dva svjetska rata, a 22 su osobe došle za vrijeme Drugoga svjetskog rata. Za osam osoba nije zabilježeno vrijeme dolaska.

Podaci o iseljavanju i doseljavanju stanovništva na prostoru današnje Republike Slovenije mogu se pronaći i u knjigama Stanje duša slovenskih župa (slov. Družinske knjige). U nekim su pograničnim župama zabilježeni odlasci osoba na prostor župa u Čabarskom kraju. U tim su knjigama i neke osobe koje su se odselile na prostor gerovske župe, tako da su to ujedno i jedini podaci o doseljavanju stanovništva sa slovenskog prostora u Gerovo i okolna mjesta. Primjerice Milan Štemberger iz Sušaka priženio se u Gerovo Milki Klepac (Status animarum Lipa-Nova vas, Novokračine-Pasjak). To nije jedini slučaj iseljavanja u Gerovo s prostora općine Ilirska Bistrica. Alojz Šetan iz Kuteževa također se priženio u Gerovo (Status animarum Kuteževo II).

Vrlo su bogati i podaci dobiveni iz knjiga Status animarum župe Stari $\operatorname{Trg}$ (Babno polje. Catalogus Cuxalia. Babenfeld. 1830, Knjiga 1., Status animarum Babinpolje od 1890. godine, Knjiga 2., Status animarum. Babinpolje, Knjiga 3. i Status animarum, Knjiga 4.). Zbog blizine mjesta broj je pojedinaca koji su se preselili u mjesta župa u Čabarskom kraju znatno veći. Tako je zabilježeno da su se s prostora župe Stari Trg na prostor župe Prezid odselile barem 34 osobe, na prostor Čabra njih deset, na prostor župe Gerovo jedna, a na prostor župe Tršće dvije. Za mnogo je osoba zabilježeno da su se odselile u Hrvatsku. Većina njih otišla je u Slavoniju i Rijeku. ${ }^{25}$

\section{ZAKLJUČAK}

Iz prikupljenih i analiziranih podataka iz knjiga Stanje duša župa Čabarskoga kraja vidi se da su veze između današnjega hrvatskog i slovenskog pograničnog prostora postojale i da su bile kontinuirane, što se i očekivalo. Kontinuiranim doseljavanjem, ali i iseljavanjem stanovništva stoljećima se stvarala mreža obiteljskih i prijateljskih veza, koja je 1991. prekinuta formiranjem državne granice. Državna granica svakako predstavlja fizičku barijeru koja ometa razvoj procesa što su se kroz povijest razvijali na goranskom prostoru (kao i u ostalim, danas pograničnim prostorima); ako i ne zaustavlja te procese, svakako im daje novu dimenziju.

Kada se promatraju uzroci doseljavanja stanovništva sa slovenskog prostora, moguće je zaključiti da su pojedinci u prvom redu dolazili zbog vjenčanja i osnivanja obitelji. Iz tih su se razloga Slovenci doseljavali na prostor

25 Valja navesti i brojne zapise koji svjedoče o internaciji stanovništva u logore, pa tako i u koncentracijski logor u Kamporu. Do sada je o toj temi napisano više radova (Jerman, 2008; Kovačič, 1998; Sobolevski, 1988; Šušteršič, 1974; Jezernik, 1983 i dr.). 
cijele Hrvatske, ne samo u pogranične dijelove. Isti su razlozi bili presudni za iseljavanje stanovništva iz hrvatskih krajeva u slovenske. Zabilježen je vrlo mali broj obitelji koje su se doselile na prostor Čabarskoga kraja, kao i onih koji su došli zbog odluke državne ili crkvene vlasti (u ovom slučaju u knjigama Stanje duša zabilježen je samo dolazak svećenika Franje Poša).

Svakako je više ljudi došlo iz krajeva koji su blizu današnje hrvatskoslovenske državne granice nego iz udaljenijih i većih mjesta (Ljubljana, Postojna, Vrhnika itd.). Sveukupno se doselilo barem 135 ljudi, a među njima je bilo više žena (96) nego muškaraca (39). Najveći broj doseljenika iz Slovenije stigao je na prostor Gorskoga kotara između dva svjetska rata (66). Promatrajući podatke o migracijama, može se ustanoviti da je postojala čvršća povezanost među pojedinim mjestima koja su danas s različitih strana državne granice, primjerice između mjesta Babno Polje i Novi Kot i naselja na prostoru župe Prezid te između mjesta Podplanina i Čabra. Ta su mjesta geografski gledano bila najbliža, pa je logično da su se najčvršće veze razvile doseljavanjem i iseljavanjem stanovnika.

Podaci dobiveni iz knjiga Stanje duša dokumentiraju postojanje migracija u prošlosti, a koliko su one i danas jake, bilo bi potrebno i vrijedno dodatno istražiti.

U daljnjim istraživanjima migracija na prostoru Gorskoga kotara svakako bi valjalo posvetiti pozornost $\mathrm{i}$ iseljavanju hrvatskoga stanovništva na prostor današnje Republike Slovenije. U dvije župe u kojima su knjige Stanje duša očuvane i relevantne mogli smo pratiti frekventnost odlazaka stanovništva na slovenske prostore. Prema podacima, iselilo se barem dvjesto ljudi, pri čemu su češće odlazile žene (131) nego muškarci (69), a zabilježeni su i odlasci cijelih obitelji. Na temelju tih pokazatelja zaključujemo da bismo na slični intenzitet odlazaka naišli i u knjigama župe Presvetog Trojstva Plešce i župe Sv. Vida u Prezidu da se iz njih moglo izvući više podataka. Svakako možemo tvrditi da su se ljudi najčešće iseljavali jer su u slovenskim mjestima osnovali obitelj. Manji je bio broj onih koji su odlazili zbog posla.

Osim trajnih migracija na prostor župa Čabarskoga kraja zabilježene su i dnevne migracije. U radu su opisane samo dnevne migracije koje su se odnosile na djecu u osnovnoj školi, dok bi iscrpnija analiza prekograničnih odnosa vjerojatno pokazala cijelu lepezu svakodnevnih, povremenih ili kontinuiranih migracija. Otkrile bi se i dublje i intenzivnije veze koje čine suživot na ovdje prikazanome pograničnom prostoru, a koje su se formirale stoljećima.

Za iscrpniji pregled doseljavanja stanovništva bilo bi potrebno uključiti i druge matične knjige (knjige rođenih, vjenčanih i umrlih) jer knjige Stanje 
$d u s ̌ a$ imaju, kao primarni izvori, nedostataka. To je u prvom redu neredovito i nepotpuno zapisivanje podataka iz objektivnih, ali i subjektivnih razloga. Tome u prilog ide primjer Gerova, u kojem su matične knjige (kao i knjige Stanje duša) spaljene u Drugome svjetskom ratu. To je, svakako, objektivan razlog nedostatka podataka i knjiga kao izvora. No valja uzeti u obzir i nedovoljnu pomnju i savjesnost pojedinih župnika u vođenju evidencije. U nekim slučajevima podaci u knjigama nisu detaljno zapisani, pa iako su relevantan izvor za promatranje sastava i migracija stanovništva na nekom prostoru, nisu i dostatan izvor. Primjer nepotpunih knjiga Stanje $d u s ̌ a$ jesu one župe Plešce, u kojima je zabilježen dolazak samo triju osoba $\mathrm{s}$ prostora današnje Republike Slovenije. Tako niski broj demantira i osnovna literatura o povijesti toga mjesta te bi stoga detaljnija istraživanja vjerojatno pokazala da je broj doseljenika bio veći.

Nesumnjiva su prednost knjiga Stanje duša zapisani individualni razlozi dolaska pojedinaca na određeni prostor. Ti podaci nadopunjavaju statističke podatke o migracijama i omogućuju sagledavanje životne realnosti u kretanju stanovništva. Na temelju tih individualnih, pa čak i intimnih razloga dolaska i odlaska pojedinaca i obitelji mogu se izvući uopćeni zaključci za određeni geografski prostor i određeno političko-povijesno razdoblje. Tako povijest određenoga kraja postaje povijest njegovih stanovnika, kako onih trajno naseljenih tako i onih doseljenih. U njoj bi trebalo biti mjesta i za sudbine iseljenih, čemu bi svakako valjalo posvetiti pozornost $u$ budućim istraživanjima.

Istraživanje je pokazalo ljudsku, obiteljsku i osobnu povezanost stanovništva Čabarskoga kraja s prekograničnim slovenskim prostorom. Osim u pravno-političkim i ekonomskim razlozima i u tome svakako leži tradicionalna bliskost tih prostora, srodnost načina života i drugih izbora. Na tim prostorima pojmovi »asimilacija « $\mathrm{i}$ »integracija « dobivaju dodatno značenje, čime bi se vrijedilo pozabaviti.

\section{IZVORI}

Babno polje. Catalogus Cuxalia. Babenfeld. 1830. Knjiga 1., Župni ured Stari Trg

DAR (Državni arhiv u Rijeci), Stališ duša I , DVD 04, ZM-34J-208, slika MO 1801737

DAR (Državni arhiv u Rijeci), Status animarum XIX-XX, DVD 5, ZM-34J/214

DAR (Državni arhiv u Rijeci), Status animarum 1935-1978, DVD 5, ZM34J-215, ZM34J-216

DAR (Državni arhiv u Rijeci), Stališ duša župe Čabar, DVD 04, ZM-34J-208 
DAR (Državni arhiv u Rijeci), Stališ duša župe Prezid, DVD 05, ZM-34J-214

DAR (Državni arhiv u Rijeci), Stališ duša župe Tršće, DVD 05, ZM-34J-214

Dneonik, imenik, 1954/1955-1959/1960, Osnovna škola Čabar

Glavni imenik 2. Osnovne narodne škole Prezid od godine 1945./1946., Osnovna škola Čabar Glavni imenici 1943./1944.- 1947./1948, Osnovna škola Čabar

Glavni imenik od 1945./1946. do 1953./1954. godine, Osnovna škola Čabar

Glavni imenik školskih sposobnjaka niže pučke škole u Prezidu od 1. 9. 1904., Osnovna škola Čabar

Matična knjiga Čabar I od 7. 1. 1960 do 30. 6. 1964, Osnovna škola Čabar

Matična knjiga 3, Osnovna škola Čabar

Matična knjiga 1962./1963. od 1. do 22., Osnovna škola Čabar

Matična knjiga Osnovne škole »Janeš Ivan« - Prezid. Svezak 5., od 1. 9. 1969. godine i od red. broja 1., Osnovna škola Čabar

Popis školskih sposobnjaka za školsku godinu 1919./1920., Osnovna škola Čabar

Osnovna škola Prezid. Razredba knjiga osmog (VIII) razreda za šk. godinu 1962./1963., Osnovna škola Čabar

Osnovna škola Prezid. Matična knjiga svezak 4. od 1. 9. 1962. do 30. 8. 1969. godine. Od red. broja 1. do 392., Osnovna škola Čabar

Status animarum Babinpolje od 1890. godine, Knjiga 2., Župni ured Stari Trg

Status animarum. Babinpolje, Knjiga 3., Župni ured Stari Trg

Status animarum Lipa-Nova vas, Novokračine-Pasjak, Župa Jelšane

Status animarum Kuteževo II., Župa Podgraje

Status animarum, Knjiga 4., Župni ured Stari Trg

\section{LITERATURA}

Arh, B. (ur.) (1998). Tršće. Čabar: Finvest corp.

Balkovec, B. (2003). Paberki o rojstvu in porokah v župniji Preloka, Kronika, 51 (1): 51-60.

Bertoša, S. (2000). Puljske matične knjige kao izvor za povijest migracija: doseljenici iz središnje Hrvatske, Ugarske i slovenskih zemalja pod austrijskom vlašću (16131817), Povijesni prilozi, 19 (19): 181-198.

Bertoša, S. (2001). Doseljenici iz Kopra i njegove okolice u matičnim knjigama od 1613 do 1817., Acta Histriae, 9 (2): 389-414.

Blaznik, P. (1979). O preselitvi loških podložnikov, Loški razgledi, 26 (26): 77-89.

Bognar, I. H. i Bognar, A. (2010). Povijesni razvoj i političko-geografska obilježja granice i pograničja Republike Hrvatske s Republikom Slovenijom na Žumberku i u Kupskočabranskoj dolini, Geoadria, 15 (1): 187-224.

Burić, A. (1983). Povijesna antroponimija Gorskog kotara u Hrvatskoj: 1438-1975. Rijeka: Društvo za zaštitu prirodne kulture i povijesne baštine Gorskog kotara.

Čavrak, V. (1999). Status animarum=(Stanje duša): povijest sela Letovanci. Sisak: Radio Sisak.

Drnovšek, M. (1995). Slovenski izseljenci na Hrvaškem do 1914, u: V. Kržišnik Bukić (ur.). Slovenci v Hrvaški. Ljubljana: Inštitut za narodnostna vprašanja, 107-114. 
Drnovšek, M. (2012). Slovenski izseljenci in Zahodna Evropa v obdobju prve Jugoslavije. Ljubljana: Založba ZRC, ZRC SAZU.

Hirc, D. (1996). Gorski kotar. Rijeka: Tiskara Rijeka.

Horvat, J. (1980). Kultura Hrvata kroz 1000 godina. Zagreb: Globus.

Hreljević, A. (1965). Ravna Gora, Vjesnik Historijskog arhiva u Rijeci, 10 (10): 1964-1965.

Hudales, J. (1997). Od zibeli do groba. Ljubljana - Velenje: Društvo za preučevanje zgodovine, literature in antropologije - Kulturni centar Ivana Napotnika.

Janež, H. (2008). Kampor na otoku Rabu: koncentracijsko taborišče. Ljubljana: Taboriščni odbor Rab-Gonars pri Koordinacijskem odboru žrtev vojnega nasilja ZZB NOB Slovenije.

Jezernik, B. (1983). Boj za obstanek: o življenju Slovencev v italijanskih koncentracijskih taboriščih. Ljubljana: Borec.

Karaman, I. (1958-1959). Komorska gospoštija Čabar 1787-1798, Historijski zbornik, 11-12: 259-282.

Knežević-Hočevar, D. (1999). Družbena razmejevanja v dolini zgornje Kolpe. Ljubljana: Založba ZRC.

Kovač, M. D. (1993). Stare slave domovina. Hanau: Hrvatska katolička misija.

Kovačič, I. (1998). Kampor 1942. - 1943.: Hrvati, Slovenci i Židovi u koncentracijskom logoru Kampor na Rabu. Rijeka: »Adamić«.

Kolar, B. (1996). Status animarum kot arhivsko gradivo, Drevesa, 3 (2): 4-8.

Kržišnik-Bukić, V. (1994/1995). Okvirni pregled poteka, vzrokov in pomena izseljevanja Slovencev na Hrvaško, Razprave in gradivo, 5 (29-30): 85-93.

Kuzmič, M. (1995). Izseljevanje iz Prekmurja med prvo in drugo svetovno vojno v luči sodelavcev Mladega Prekmurca, Zbornik soboškega muzeja, 4 (10): 103-110.

Lajić, I. i Klempić Bogadi, S. (2010). Demografska budućnost Gorskog kotara, Migracijske i etničke teme, 26 (2): 191-212.

Laszowski, E. (1923). Gorski kotar i Vinodol. Zagreb: Matica hrvatska.

Lukežić, I. (2007). Fluminensia Slovenica. Rijeka: ICR.

Malnar, S. (2007). Povijest čabarskog kraja. Čabar: Ogranak Matice Hrvatske u Čabru.

Malnar, Ž. (2010). Povijesna kronologija čabarskog kraja. Čabar: Ogranak Matice Hrvatske u Čabru.

Marković, M. (2003). Gorski kotar. Zagreb: Naklada Jesenski i Turk.

Melik, A. (1959). Posavska Slovenija. Ljubljana: Slovenska matica.

Munić, V. (1996/1997). Status animarum Clanae, u: V. Tadejević (ur.). Ivan Matetić Ronjgov: zbornik, sv. 5. Rijeka: Udruga Ivan Matetić Ronjgov, 187-198.

Pavlin, V. (1997). Prebivalstvo v solkanski župniji 1835-1864, Goriški letnik, 24 (24): 35-54.

Petešić, Ć. i Bilandžić, D. (1982). Katoličko svećenstvo u NOB-u: 1941-1945. Zagreb: Globus.

Podobnik, G. (2005). Zavičaju. Ravna Gora: Općina Ravna Gora.

Radanovič, S. (1992a). Mesto Maribor v luči matičnih knjig 17. stoletja, Kronika, 39 (3): 32-39.

Radanovič, S. (1992b). Kamnica in njeni prebivalci v 17. stoletju v luči matičnih knjig, Časopis za zgodovino in narodopisje, 63 (2): 280-316. 
Ravnik, M. (1994). Sestava in preteklost istrskih družin v terenskem in arhivskem gradivu, Buzetski zbornik, 19: 39-44.

Ravnik, M. (1996). Bratje, sestre, strniči, zermani: družina in sorodstvo v vaseh v Slovenski Istri. Ljubljana: Znanstvenoraziskovalni center Slovenske akademije znanosti in umetnosti.

Ravnik, M. (1997). Status animarum v nekaterih etnoloških raziskavah, Drevesa, 4 (2-3): 28-29.

Senčić, A. (2000). Popis pučanstva župe Mošćenice iz godine 1801: knjiga Stališ duša. Opatija: Katedra Čakavskog sabora.

Smole, M., (2006). Zgodba družine Čop iz hrvaške obmejne vasi Plešce v Čabranski dolini, u: K. M. Hirnök i M. Ravnik (ur.). Slovenci na Hrvaškem - dediščina in sedanjost. Ljubljana: Slovensko etnološko društvo, 223-234.

Sobolevski, M. (1988). Kampor - Rab: 1942-1943: koncentracioni logor. Rab: Skupština općine.

Šafar, J. (ur.) (1981). Gorski kotar. Delnice: Fond knjige »Gorski kotar«.

Šövegeš Lipovšek, G. (2001). Prebivalstvo Lendave na podlagi matičnih knjig med 1909 in 1919, Časopis za zgodovino in narodopisje, 72 (1-2): 97-121.

Stipetić, V. i Vekarić, N. (2004.). Povijesna demografija Hrvatske. Zagreb - Dubrovnik: Hrvatska akademija znanosti i umjetnosti, Zavod za povijesne znanosti u Dubrovniku.

Šušteršič, F. (1974). Taborišče Kampor Rab: 1943-1973. Rijeka: Muzej narodne revolucije.

Valenčič, R. (2010). Prispevek slovenskih duhovnikov reški škofiji 1924-1951., Bistriški zapisi, 10 (7): 7-18.

Vlahov, D. (1992-1993). Matične knjige u povijesnom arhivu u Pazinu, Vjesnik Istarskog arhiva, 2-3 (2-3): 277-309.

Wolf, M. B. (ur.) (2006). 120 godina vatrogastva u Prezidu. Prezid: Dobrovoljno vatrogasno društvo Prezid.

Žigulić, R. (2008). Stališ duša župe Veprinac: 1875. - 1925. Rijeka: Državni arhiv u Rijeci. 


\title{
The Immigration of People from Slovenian Regions to the Čabar Region Based on the Notes from Ecclesiastical Status Animarum Books
}

\section{Barbara Riman}

\begin{abstract}
SUMMARY
The area of Gorski kotar was in history a site with a variety of migratory processes which influenced the ethnical particularities of that area. These migrations were the reason for the heterogeneous composition of the present population of the Gorski kotar region. The Čabar region was not an exception to this, and throughout history there existed a written record of the immigration of people from all over the Habsburg Monarchy. Especially intensive was the immigration in the areas situated near the Kupa and Cabranka rivers. The reasons for immigration and for its intensity can be seen in the notes written down in the church books named Status Animarum (cro. Stanje duša, slo. Družinske knjige). The immigration or emigration reasons of individuals as well as of whole families have been noted in these books. On the basis of these notes we can draw conclusions regarding the level of generalization for the precise geographical area and the precise political and historical period, which becomes a relevant and credible basis for theoretical considerations and a comparative analysis. In this manner, the history of the geographical area becomes the history of the area's residents, both those permanently inhabited and those who settled subsequently. This paper will focus on the immigration of people in the Čabar area from present-day Slovenian regions during the $19^{\text {th }}$ and $20^{\text {th }}$ century. The data obtained from the Status Animarum books, which were written in the parishes of the Čabar region, show the immigration of people, which proves migration from Slovenian regions to the Croatian ones, but also vice versa. The conclusions of the paper will be illustrated and backed with data obtained from the Status Animarum books originating from Slovene parishes Babno Polje and Jelšane, and with additional information from elementary school registers in Prezid and Čabar.
\end{abstract}

KEY WORDS: Status Animarum, Čabar region, Gorski kotar, Slovenian population immigration 